\title{
WODA W STOSUNKACH PRAWNYCH - DZIEŁO AUTORÓW CZESKICH Z PERSPEKTYWY POLSKIEJ
}

\section{WATER IN LEGAL RELATIONS - WORK OF THE CZECH AUTHORS FROM THE POLISH POINT OF VIEW}

http://dx.doi.org/10.12775/PPOS.2016.005

\section{Artykuł recenzyjny}

Ivana Průchova, Jakub Hanak a kolektiv, Voda $v$ pravnich vztazich, Spisy Pravnicke fakulty Masarykovy univerzity, řada teoreticka č. 481, Brno 2014, s. 238.

* Zakład Zagadnień Prawnych Kształtowania i Ochrony Środowiska INP PAN we Wrocławiu.

** Zakład Zagadnień Prawnych Kształtowania i Ochrony Środowiska INP PAN we Wrocławiu. 


\section{STRESZCZENIE}

Wydawnictwo Uniwersytetu Masaryka w Brnie opublikowało niezwykle interesujące dzieło zbiorowe autorów czeskich zawierające szesnaście opracowań poświęconych wybranym zagadnieniom czeskiego prawa wodnego w trzech kręgach tematycznych: 1) ochrona wód przy wykorzystywaniu terenów, 2) woda w stosunkach prywatnoprawnych, 3) ochrona jakości wód. Celem tego szkicu jest przedstawienie podstawowych myśli autorów czeskich oraz próba oceny, czy znajdują one lub powinny znaleźć odzwierciedlenie w rozważaniach nad polskim prawem wodnym.

\section{Słowa kluczowe}

Woda; prawo wodne; ochrona wód; ochrona przyrody; ochrona środowiska.

\section{ABSTRACT}

The publishing house of the Masaryk University in Brno has published a very interesting work of the Czech authors containing sixteen studies devoted to selected problem of the Czech water law in three subject areas: 1) water protection in land use, 2) water in private legal relations, 3) protection of water quality. The aim of this paper is to present basic thoughts of the Czech authors and an attempt to estimate if they find or should find a reflection in the deliberations on the Polish water law.

\section{Keywords}

Water; water law; water protection; nature protection; environmental protection.

Opublikowane w 2014 r. dzieło zbiorowe Ivany Průchovej, Jakuba Hanaka i kilkunastu autorów czeskich poświęcone wodzie w stosunkach prawnych zostało podzielone na cztery części, spośród których trzy są poświęcone prawu czeskiemu (ochrona wód przy wykorzystywaniu gruntów, woda w stosunkach prywatnoprawnych, ochrona jakości wód), czwarta zaś wybranym 
problemom prawa wodnego w Polsce (szkice Mateusza Sieńki o spółkach wodnych oraz Jarosława Pomarańskiego o nowelizacji polskiego prawa wodnego dopuszczającej ruch rowerowy na wałach przeciwpowodziowych). Zajmiemy się niezwykle interesującymi rozważaniami autorów czeskich, stawiając pytanie, czy wyodrębnili oni rzeczywiście kluczowe problemy współczesnego prawa wodnego oraz czy poruszane przez nich problemy znajdują bądź powinny znaleźć odzwierciedlenie w badaniach polskiego prawa wodnego.

\section{OCHRONA WÓD PRZY WYKORZYSTYWANIU TERENÓW (OCHRANA VOD PŘI VYUŽIVANI UZEMI)}

\subsection{MICHAL SOBOTKA, ROZWIĄZYWANIE POTENCJALNYCH KONFLIKTÓW PRZY KORZYSTANIU Z WÓD ( $\check{E}$ ĚSENI POTENCIALNICH KONFLIKTU゚ P̌̌I NAKLADANI S VODAMI)}

Autor zaczyna spostrzeżeniem, że wymagania wobec wód mogą generować dwa rodzaje konfliktów. W pierwszym przypadku chodzi o zderzenie interesu ludzi w wykorzystywaniu zasobu wód z jego funkcjami ekologicznymi (konflikt publiczny), w drugim o sytuacje, kiedy wydajność zasobu wodnego nie odpowiada indywidualnym wymaganiom konkretnego użytkownika bądź konkurują one z indywidualnymi wymaganiami innego konkretnego użytkownika (konflikt indywidualny). Powstaje pytanie, czy regulacja prawna umożliwia zapobieganie konfliktom obu typów lub ich rozwiązywanie.

Dostęp do zasobów wodnych i ich wykorzystywania jest w Republice Czeskiej przedmiotem regulacji publicznoprawnej. Czeska ustawa wodna ${ }^{1}$ wyklucza instytucję własności w odnie-

1 Zakon č. 254/2001 Sb., o vodach (vodni zakon). Przypominamy, że czeskie akty prawne powoływane są w ten sposób, że po literze „čc” następuje pozycja, pod którą akt został opublikowany w urzędowym zbiorze aktów prawnych (Sbirka zakonů), łamana przez rok publikacji i zakończona literami „Sb.” (skrótem owego zbioru). 
sieniu do wód powierzchniowych i podziemnych, a dostęp do nich uzależnia od spełnienia warunków w niej przewidzianych. Jedną z podstawowych kategorii pojęciowych ustawy jest nakladani s povrchovymi nebo podzemnimi vodami, które $\S 2$ ust. 9 definiuje jako ich piętrzenie za pomocą inwestycji wodnych, wykorzystywanie ich potencjału energetycznego, wykorzystywanie dla żeglugi lub spławu drewna, hodowli ryb lub drobiu wodnego, pobieranie ich, odprowadzanie do nich ścieków i inne sposoby, którymi można wykorzystywać ich właściwości lub wpływać na ich ilość, przepływ, występowanie lub jakość.

Przepis § 6 ustawy wodnej regulujący Obecne nakladani s povrchovymi vodami stanowi, że każdy może na własne ryzyko bez pozwolenia ani zgody urzędu wodnoprawnego pobierać wody powierzchniowe lub w inny sposób z nimi postępować na własne potrzeby, jeżeli nie trzeba do tego szczególnego urządzenia technicznego ( $\S 6$ ust. 1). Pozwolenie ani zgoda również nie są potrzebne na ujmowanie wód powierzchniowych prostymi urządzeniami na poszczególnych gruntach i budowach albo na zmianę naturalnego odpływu w celu ich ochrony przed szkodliwym oddziaływaniem tych wód (§ 6 ust. 2). Ale zgodnie z $\S 6$ ust. 3 przy powszechnym korzystaniu z wód powierzchniowych nie wolno zagrażać ich jakości ani zdrowotnej nieszkodliwości wód, naruszać środowiska przyrodniczego, pogarszać stosunków odpływowych, uszkadzać brzegów, inwestycji i urządzeń wodnych, urządzeń chowu ryb ani naruszać praw i prawem chronionych interesów innych podmiotów. Jest to reżim wspólny dla wszystkich użytkowników. Intensywność korzystania jest niewielka i praktycznie nie ma ryzyka zagrożenia funkcji ekologicznych bądź interesów innych użytkowników, a zabezpieczeniem jest $\S 6$ ust. 4, który pozwala urzędowi wodnoprawnemu bez odszkodowania uregulować, ograniczyć lub zakazać powszechnego korzystania $\mathrm{z}$ wód, jeżeli wymaga tego interes publiczny, zwłaszcza jeżeli dochodzi do naruszenia obowiązków wskazanych w ust. 3, albo ze względu na bezpieczeństwo osób. Urząd może to uczynić bądź decyzją administracyjną (rozhodnutim), wtedy regulacja odnosi się do konkretnego podmiotu, bądź aktem administracyjnym o charakterze ogólnym (opatře1/2016 nim obecne povahy), wtedy regulacja odnosi się do wszystkich. 
Odmiennie przedstawia się szczególne korzystanie z wód zawsze wymagające pozwolenia będącego podstawowym instrumentem prewencyjnym pozwalającym tak ustawić parametry, aby nie dochodziło do konfliktu interesów, czy to indywidualnych, czy publicznych. Ustawa wodna w $\S 12$ pozwala na zmianę lub uchylenie pozwolenia w określonych przypadkach, co umożliwia rozwiązywanie konfliktów.

Priorytetowo traktuje się zawsze zaopatrzenie ludności w wodę pitną, co w odniesieniu do wód podziemnych ustawa stanowi wprost, a do czego w odniesieniu do wód powierzchniowych można dojść drogą interpretacji. Jeśli jednak chodzi o inne interesy, to ustawa nie daje żadnych wskazówek, pozostawiając rozstrzygnięcie urzędowi wodnoprawnemu, granice jego uznania nie są dostatecznie uregulowane. Można posłużyć się konstrukcją wzorowaną na prawie międzynarodowym „rozumnego i sprawiedliwego" korzystania z wód.

Prewencja i rozwiązywanie konfliktów publicznych jest uregulowane lepiej. Podstawowe znaczenie ma ramowa dyrektywa wodna $2000 / 60 / \mathrm{WE}^{2}$ orientująca się na dobry stan wód i służące osiągnięciu tego celu plany i programy.

W odniesieniu do zasad korzystania z wód oraz wyposażenia organów administracji wodnej w instrumenty służące rozstrzyganiu konfliktów powstających na tym tle, unormowania polskiego prawa wodnego wydają się zbieżne z czeskimi. Występują jednak różnice, co jest zrozumiałe. Wskazać należy przede wszystkim na stopniowo rozwijane w drodze kolejnych nowelizacji zasady rozstrzygania konfliktów w przypadku, gdy o wydanie pozwolenia wodnoprawnego ubiega się kilka zakładów, których działalność wzajemnie się wyklucza z powodu stanu zasobów wodnych (art. 123 ust. 1 i 2). Ustawa ${ }^{3}$ stanowi, że pierwszeństwo mają zakłady, które będą pobierać wodę w celu zaopatrzenia ludności w wodę do spożycia (co prawo czeskie

2 Dyrektywa 2000/60/WE Parlamentu Europejskiego i Rady z dnia 23 października 2000 r. ustanawiająca ramy wspólnotowego działania w dziedzinie polityki wodnej, Dz.Urz. UE L 327 z 22.12.2000, s. 1-73.

3 Ustawa z dnia 18 lipca 2001 r. Prawo wodne, tekst jedn. Dz.U. z 2015 r., poz. 469 ze zm. 
także przewiduje), a następnie zakłady, których korzystanie z wód przyczyni się do zwiększenia naturalnej lub sztucznej retencji wód lub poprawy stosunków biologicznych w środowisku wodnym, a w dalszej kolejności właściciele oraz posiadacze samoistni i zależni innych obiektów, instalacji lub urządzeń infrastruktury krytycznej. Nadto pierwszeństwo przysługuje właścicielowi urządzenia wodnego koniecznego do realizacji tego pozwolenia (art. 123 ust. 1a). Preferencje przy poborze wody podziemnej dla podmiotów wykorzystujących wody podziemne do zaopatrzenia ludności oraz na potrzeby produkcji artykułów żywnościowych oraz farmaceutycznych przewiduje także art. 32, o nieco szerszym zakresie niż adekwatne przepisy czeskie. Przypomnieć w tym miejscu można, że wzorem legislacyjnego rozwiązania tego problemu pozostaje art. 54 ustawy wodnej z dnia 19 września 1922 r. Wiodącym kryterium jest w nim znaczenie przedsięwzięcia dla dobra publicznego, następnie jego znaczenie gospodarcze. Jeśli o pozwolenie ubiegało się kilka „równych sobie” zakładów (stosowano pojęcie „przedsiębiorstwa"), pierwszeństwo uzyskiwały istniejące przed nowy$\mathrm{mi}$, następnie te, związane $\mathrm{z}$ danym miejscem, przed takimi, które mogły być zlokalizowane gdzie indziej, w końcu zakłady należące do właścicieli gruntów nadbrzeżnych przed innymi. Na wodach publicznych pierwszeństwo przysługiwało generalnie państwu, związkom samorządowym i spółkom wodnym.

Konflikty w dostępie do wody powstające na tle interesów publicznych powinny być rozstrzygane przede wszystkim na etapie planowania, na co uwagę zwracają także autorzy czescy. Odesłania do mechanizmów stworzonych przepisami ramowej dyrektywy wodnej 2000/60/WE, są tu oczywiste. Podstawy prawne do urzędowych działań w ramach administracyjnej kontroli następczej, obejmującej stwierdzanie wygaśnięcia, cofanie lub ograniczanie udzielonych pozwoleń, wydają się z kolei nieco bardziej zróżnicowane niż te, przewidziane w ustawie czeskiej. Chodzi m.in. o art. 135 - 139 różnicujące sytuacje, gdy odszkodowanie przysługuje lub nie. 


\subsection{DOMINIK ŽIDEK, WODA W PROCESACH PUBLICZNEGO PRAWA BUDOWLANEGO ${ }^{4}$ (VODA V PROCESECH VEŘEJNEHO STAVEBNIHO PRAVA)}

Celem tego szkicu jest pokazanie jak przedstawia się właściwość organów w przypadkach budownictwa wodnego. Wchodzą wtedy w rachubę trzy grupy przepisów: obok ustawy wodnej także ustawa o planowaniu przestrzennym i budownictwie $^{5}$ oraz ustawa o ogólnym postępowaniu administracyjnym ${ }^{6}$.

Punktem wyjścia jest $\S 15$ ust. 1 lit. d) ustawy budowlanej. Paragraf ten operuje pojęciem specjalnych urzędów budowlanych (specialni stavebni ur̆ady), stanowiąc w ust. 1, że kompetencje urzędu budowlanego, z wyjątkiem uprawnień w dziedzinie decyzji przestrzennych, wykonują w odniesieniu do:

a) budowli lotniczych,

b) budowli i urządzeń na drogach,

c) budowy autostrad, dróg, miejscowych połączeń komunikacyjnych i publicznie dostępnych połączeń celowych,

d) inwestycji wodnych (vodnich dèl)

organy wykonujące administrację publiczną we wskazanych dziedzinach według szczególnych przepisów prawnych.

Stosownie do § 104 ustawy wodnej administrację państwową wykonują urzędy wodnoprawne (vodopravni uřady) oraz Czeska Inspekcja Środowiska, przy czym urzędami wodnoprawnymi są:

a) urzędy gminne,

b) urzędy garnizonowe na obszarze garnizonów wojskowych,

4 W literaturze czeskiej rozróżnia się publiczne (veřejne) i prywatne (soukrome) prawo budowlane. Pierwsze dotyczy kompetencji organów i decyzji, drugie umów o roboty budowlane; zob. P. Průcha, A. Klikova, Verejne stavebni pravo, Brno 2014, s. 7.

5 Zakon č. 183/2006 Sb., o uzemnim planovani a stavebnim řadu (stavebni zakon).

6 Zakon č. 500/2004 Sb., spravni řad. 
c) urzędy gminne gmin o rozszerzonej kompetencji ${ }^{7}$,

d) urzędy okręgowe ${ }^{8}$,

e) ministerstwa jako centralny urząd wodnoprawny.

Autor omawianego szkicu uznaje za stosunkowo efektywną trójstopniową hierarchicznie zbudowaną strukturę urzędów budowlanych w gospodarce wodnej, na której czele stoją cztery dzielące się kompetencjami ministerstwa (rolnictwa, środowiska, komunikacji i obrony), a na najniższym stopniu są urzędy gminne gmin o rozszerzonej kompetencji, które mają tzw. „zbytkovou" pưsobnost, tj. wydają decyzje we wszystkich sprawach, które nie są powierzone innym organom. Do ich kompetencji należy większość decyzji związanych z publicznym prawem budowlanym (zwłaszcza w formie pozwoleń na inwestycje wodne), z wyjątkiem taksatywnie wymienionych postępowań należących do kompetencji urzędów okręgowych (np. inwestycje wodne związane $\mathrm{z}$ odprowadzaniem ścieków z pozyskiwania rud uranowych).

W końcowej części opracowania autor zwraca uwagę na $\S 115$ czeskiej ustawy wodnej, regulujący postępowanie wodnoprawne. Ustęp 6 tego paragrafu dopuszcza uczestnictwo stowarzyszeń obywatelskich (pod pewnymi warunkami), ale wyraźnie wyklucza ich uczestnictwo w postępowaniach budowlanych prowadzonych na podstawie $\S 15$ ustawy wodnej, czyli o pozwolenia budowlane na inwestycje wodne. Zdaniem autora konsekwencje tej regulacji są absurdalne, wynika z niej bowiem, że stowarzyszenie może uczestniczyć w przypadku běžnych staveb (zwykłych, codziennych robót budowlanych), ale w przy-

7 Obecni uřady obci s rozšiřrenou pưsobnosti - praktycznie chodzi o organy większych gmin, które przejęły funkcje zniesionych w 2002 r. organów administracji powiatowej. W obowiązującym stanie prawnym $\mathrm{w}$ Czechach na szczeblu terenowym nie ma już organów administracji państwowej, a ich funkcje wykonują organy administracji samorządowej.

8 Krajske uřady. Czeski kraj jest odpowiednikiem polskiego „województwa" (terytorium Republiki Czeskiej dzieli się na 14 wyższych jednostek samorządowych). Posługujemy się zalecanym przez słowniki tłumaczeniem kraju przez „okręg”, nie pozostawiamy „kraju”, aby nie sugerować, że Czechy są państwem federalnym (bo nie są), ani nie wprowadzamy „województwa”, gdyż byłoby to nieuzasadnione spolszczenie. 
padku vodnich dèl już nie, mimo że właśnie inwestycje wodne są potencjalnie najbardziej niebezpieczne dla środowiska wodnego. Autor uważa to rozwiązanie za niekonstytucyjne i proponuje powrót do stanu prawnego sprzed 1 stycznia 2013 r., kiedy takiego wyłączenia nie było.

Podobnie jak w prawie czeskim, także w Polsce unormowania dotyczące budownictwa wodnego nie zamykają się w ramach jednej ustawy, kluczowej dla gospodarowania wodami, to jest ustawy - Prawo wodne. Artykuł 62 ust. 2 przewiduje bowiem, że przepisy art. 63 - 66 nie naruszają przepisów ustawy - Prawo budowlane9. Z kolei ta ustawa wprowadza w art. 2 ust. 2 pkt 2 własną zasadę, że jej przepisy nie naruszają przepisów odrębnych, którymi w odniesieniu do urządzeń wodnych są przepisy prawa wodnego.

Krytyczne uwagi autorów czeskich dotyczące ograniczania uprawnień procesowych organizacji pozarządowych „brzmią znajomo". Chodzi o kontrowersje powstające na tle art. 127 ust. 8, w myśl którego w postępowaniach o wydanie pozwolenia wodnoprawnego nie stosuje się przepisów art. $31 \mathrm{Kpa}^{10}$, a więc tych tworzących organizacji społecznej podstawę do wszczęcia postępowania lub dopuszczenia do udziału w postępowaniu dotyczącym innej osoby, o ile jest to uzasadnione celami statutowymi tej organizacji i przemawia za tym interes społeczny. Identyczną regułę ujmuje art. 28 ust. 3 ustawy - Prawo budowlane. Z drugiej strony podkreślić należy, że możliwości partycypacji istnieją w pewnych kategoriach spraw z uwagi na treść art. 44 ust. 1 ustawy o udostępnianiu informacji o środowisku i jego ochronie, udziale społeczeństwa w ochronie środowiska oraz o ocenach oddziaływania na środowisko ${ }^{11}$.

9 Ustawa z dnia 7 lipca 1994 r. Prawo budowlane, tekst jedn. Dz.U. z 2016 r., poz. 290 ze zm.

10 Ustawa z dnia 14 czerwca 1960 r. Kodeks postępowania administracyjnego, tekst jedn. Dz.U. z 2016 r., poz. 23 ze zm.

11 Tekst jedn. Dz.U. z 2016 r., poz. 353 ze zm. Zob. uwagi K. Szumy do art. 127, [w:] Prawo wodne. Komentarz , B. Rakoczy (red.), Warszawa 2013, s. 597. 


\subsection{KAMILA KLEMENŠOVA, PODMIOTY OCHRONY PRZECIWPOWODZIOWEJ (SUBJEKTY POVODOVE OCHRANY)}

Autorka zaczyna od spostrzeżenia, że w Republice Czeskiej nie ma odrębnej ustawy o ochronie przeciwpowodziowej, którą jej zdaniem celowe byłoby przyjąć na wzór Republiki Słowackiej $^{12}$. Na razie w Czechach jest to materia ustawy wodnej, której rozwiązania uwzględniają postanowienia unijnej dyrektywy „powodziowej” 2007/60/WE ${ }^{13}$.

Ochrona przed powodziami została uregulowana w rozdziale IX czeskiej ustawy wodnej (§ 63-87). W § 66 ust. 1 znajduje się definicja obszarów zalewowych (zaplavova uzemi) - są nimi administracyjnie określone obszary, które przy wystąpieniu naturalnej powodzi mogą być zalane wodą. Wyznacza je urząd wodnoprawny na wniosek zarządcy cieku wodnego na podstawie odpowiedniego aktu wykonawczego. Ten akt wprowadził pojęcie aktywnej strefy obszaru zalewowego (aktivni zona zaplavoveho uzemi) - tereny zabudowane gmin oraz przeznaczone pod zabudowę według planów przestrzennych, która to strefa przy powodzi odprowadza decydującą część całościowego przepływu i tym samym bezpośrednio zagraża życiu, zdrowiu i mieniu ludzi. Zakaz budowy obowiązuje tylko dla aktywnej strefy obszaru zalewowego. W pozostałej części obszaru zalewowego warunkiem podjęcia budowy jest zgoda urzędu wodnoprawnego. Jeżeli teren zalewowy nie został wyznaczony, ale z niebezpieczeństwem powodzi należy się liczyć, to wprowadzenie zakazu zabudowy jest mocno utrudnione. Autorka ma świadomość, że zakaz zabudowy jest ingerencją w prawo własności nieruchomości. Rozwiązania szuka w pla-

12 Tym aktem słowackim jest Zakon č. 7/2010 Z.z. z 2. decembra 2009 o ochrane pred povodňami. Jest to obszerny akt prawny liczący 53 rozbudowane paragrafy.

13 Dyrektywa 2007/60/WE Parlamentu Europejskiego i Rady z dnia 23 października 2007 r. w sprawie oceny ryzyka powodziowego i zarządzania nim, Dz.Urz. UE L 288 z 6.11.2007, s. 27-34. 
nach przestrzennych, przy których przygotowywaniu podmioty w tym uczestniczące mogą się wypowiedzieć i spróbować ograniczyć zabudowę w przypadku występowania ryzyka powodziowego na tym terenie.

Poważne konflikty powstające na tle zakazu zabudowy na obszarach zagrożonych powodzią powstają także w Polsce. Sformułować można pogląd, że na etapie prac legislacyjnych sprowadzają się one zawsze do sporu o to, który podmiot poniesie koszty ograniczenia praw do nieruchomości. Obowiązki planistyczne z zakresu ochrony przed powodzią zostały w Polsce nałożone w głównej mierze na Prezesa Krajowego Zarządu Gospodarki Wodnej, gdyż to on sporządza mapy zagrożenia powodziowego oraz mapy ryzyka powodziowego (art. 88f). Z drugiej strony mapy tego rodzaju nie wprowadzają samoczynnie żadnych ograniczeń czy zakazów, gdyż dopiero wymagają dalszych czynności dostosowawczych, polegających na uwzględnieniu granic krytycznych obszarów w innych aktach planistycznych (tj. w koncepcji przestrzennego zagospodarowania kraju, planie zagospodarowania przestrzennego województwa, miejscowym planie zagospodarowania przestrzennego oraz w decyzji o ustaleniu lokalizacji inwestycji celu publicznego lub decyzji o warunkach zabudowy) ${ }^{14}$. W ocenie tego zjawiska krzyżują się argumenty racjonalne (złożoność procedur planistycznych oraz potrzeba dostrzeżenia kompetencji planistycznych gmin) oraz egoizmy resortowe (pokusa przerzucenia ciężaru konsekwencji decyzji na inny podmiot publiczny). Zarówno w Polsce, ja i Czechach system planów służących ochronie przed powodzią nawiązuje do dyrektywy 2007/60/WE PE i Rady w sprawie oceny ryzyka powodziowego i zarządzania nim.

14 Por. uwagi Z. Bukowskiego do art. 88f, [w:] Prawo wodne. Komentar\%...., s. 453. 


\subsection{JAKUB HANAK, MARIE POLAČKOVA, BUDOWNICTWO NA OBSZARACH ZALEWOWYCH (STAVEBNI ČINNOST V ZAPLAVOVYCH UZEMICH)}

Autorzy zwracają uwagę, że ochrona przed powodziami jest interesem publicznym. Najznaczniejsze ograniczenia są związane z aktywną strefą obszaru zalewowego, ale ona jest wyznaczana nie tylko dla ochrony mienia. Strefa odprowadza decydującą część przepływu wody, a jeżeli tak, to jej zabudowanie stanowi przeszkodę $\mathrm{w}$ odpływie i zwiększa zagrożenie dalszego (rozleglejszego) obszaru. Na tym tle autorzy stawiają pytanie, czy właściciele nieruchomości w aktywnej strefie, w której przed wyznaczeniem budownictwo było dozwolone, a nawet zaplanowane, mają roszczenie o rekompensatę za ograniczenie wartości nieruchomości spowodowane zakazem zabudowy. Uważają, że w zasadzie tak, ale jeżeli wpływ wyznaczonej aktywnej strefy obszaru zalewowego jest minimalny, to roszczenia o rekompensatę nie ma. Swoje stanowisko uzasadniają tym, że państwo przeznacza znaczne środki na realizację przedsięwzięć przeciwpowodziowych, jest przeto uzasadnione, aby także inne dotknięte podmioty przyczyniały się do ponoszenia tych kosztów.

Właściciele nieruchomości objętych zakazem zabudowy $\mathrm{z}$ uwagi na interes publiczny (ochrona przed powodzią) także w Polsce mogą się ubiegać o odszkodowanie na zasadach ogólnych, o ile zakaz został wprowadzony już w trakcie wykonywania prawa własności. Tryb dochodzenia zależeć będzie od formy, w jakiej ograniczenie prawa nastąpiło. Jeśli jest ono konsekwencją przyjęcia planistycznego aktu prawa miejscowego, to zastosowanie znajdą przepisy ustawy o planowaniu i zagospodarowaniu przestrzennym (art. 36). Szczególnym przypadkiem jest ustalenie reżimu prawnego obszarów narażonych na niebezpieczeństwo powodzi przez dyrektora regionalnego zarządu gospodarki wodnej w drodze aktu prawa miejscowego na podstawie art. $88 \mathrm{~m}$ ustawy - Prawo wodne. W takim przypadku znajdzie zastosowanie art. 187 ust. 1 tejże ustawy, umożliwiający wysunięcie roszczenia o odszkodowanie za 
poniesioną szkodę albo o wykup nieruchomości lub jej części. Jeśli zakaz płynie wprost z ustawy (np. zakaz wykonywania obiektów budowlanych w odległości mniejszej niż $50 \mathrm{~m}$ od stopy wału po stronie odpowietrznej), to odszkodowanie nie przysługuje.

\subsection{IVANA PRŮCHOVA, OBSZARY WODNE JAKO ZNACZĄCE ELEMENTY KRAJOBRAZOWE Z PUNKTU WIDZENIA PRAWA}

\section{(VODNI PLOCHY JAKO VYZNAMNY KRAJINNY PRVEK Z POHLEDU PRAVA)}

Jedną z form prawnych ochrony przyrody według czeskiej ustawy o ochronie przyrody i krajobrazu ${ }^{15}$ jest znaczący element krajobrazowy (vyznamny krajinny prvek). Według § 6 tej ustawy wyróżnia się dwie kategorie takich elementów. Pierwszą z nich są znaczące elementy krajobrazowe ex lege: lasy, torfowiska, cieki wodne, stawy, jeziora, doliny rzeczne; jest to wyliczenie taksatywne. Do drugiej należą te, które jako znaczące elementy krajobrazowe zostały zarejestrowane przez organ ochrony przyrody i krajobrazu; ich wyliczenie jest już tylko demonstracyjne: mokradła, obszary stepowe, remizy, miedze, trwałe obszary trawiaste, miejsca występowania minerałów i skamieniałości, sztuczne i naturalne twory skalne, wychodnie i odkrywki, ale także cenne przestrzenie porostów w miejscach osiedlenia, w tym historyczne ogrody i parki. To nie są szczególne formy ochrony przyrody, a ochrona znaczących elementów krajobrazowych jest zapewniana w ramach powszechnej ochrony przyrody.

Autorka zwraca uwagę, że obszary wodne są z reguły znaczącymi elementami krajobrazowymi. Także porosty brzegowe rosnące w korycie cieku wodnego i na jego brzegach są, jej zdaniem, znaczącymi elementami krajobrazowymi, ze wszystkimi wynikającymi stąd konsekwencjami.

15 Zakon č. 114/1992 Sb., o ochraně přirody a krajiny. 
Dalej autorka przedstawia szczegółowo formy ochrony znaczących elementów krajobrazu dochodząc do wniosku, że ochrona obszarów wodnych jako znaczących elementów krajobrazowych i tym samym jako obiektów przyrodniczych w ogóle, a obiektów ochrony krajobrazu w szczególności jest zapewniana licznymi środkami prawnymi. Podstawowe znaczenie przypisuje instytucji wiążącego stanowiska organu ochrony przyrody i krajobrazu przewidzianemu w $\S 4$ ust. 2 ustawy o ochronie przyrody i krajobrazu, które jest wymagane w odniesieniu do każdej ingerencji mogącej prowadzić do uszkodzenia lub zniszczenia znaczącego elementu krajobrazowego. Istotne znaczenie mają także przepisy nakazujące przywrócenie znaczącego elementu krajobrazowego do stanu poprzedniego oraz przepisy sankcyjne.

Reżim prawny obszarów wodnych także w Polsce jest zróżnicowany. Ustawa Prawo wodne odnosi się do ich walorów krajobrazowych tylko w dorozumiany sposób, wskazując np. w art. 38 ust. 1, że woda jest integralną częścią środowiska i siedliskiem dla zwierząt oraz roślin, zaś celem ochrony wód jest nie tylko utrzymanie lub poprawa jakości wód, ale także biologicznych stosunków w środowisku wodnym i na terenach podmokłych. W ślad za ramową dyrektywą wodną ustawa włącza do zbiorczej kategorii celów środowiskowych także te, związane z obszarami chronionymi, tworzonymi na podstawie odrębnych przepisów. Ochronie obszarów wodnych służyć będą w pierwszej kolejności zróżnicowane formy ochrony przyrody, przewidziane w ustawie o ochronie przyrody ${ }^{16}$.

\subsection{JITKA BĚLOHRADOVA, MICHAELA KONEČNA, PRAWNE ASPEKTY SPŁYWU WODAMI W PARKACH NARODOWYCH (PRAVNI ASPEKTY SPLOUVANI VOD V NARODNICH PARCICH)}

Autorki analizują $\S 16$ czeskiej ustawy o ochronie przyrody i krajobrazu określający podstawowe warunki ochrony parków

16 Ustawa z dnia 16 kwietnia 2004 r. o ochronie przyrody, tekst jedn. Dz.U. 2015, poz. 1651 ze zm. 
narodowych, który pod lit. e) stanowi, że na całym obszarze parku narodowego zakazuje się m.in. sportów wodnych poza miejscami wyznaczonymi za zgodą organu ochrony przyrody. Pod tę literę podpada, zdaniem autorek, spływ (np. kajakowy) wodami w parku narodowym. Po zbadaniu regulaminów czterech czeskich parków narodowych (Krkonošsky, Šumava, Podyji, Česke Šrycarsko) i informacji przedstawionych przez te parki autorki dochodzą do wniosku, że rozwiązaniem właściwym byłoby przełamanie zakazu z $\S 16$ ust. 1 lit. e) ustawy i dopuszczenie spływu wodami parku narodowego albo w regulaminie parku (navštěvni řad), co odnosiłoby się do nieoznaczonego kręgu osób, albo decyzją indywidualną o dopuszczeniu wyjątku według § 43 ustawy.

Co do zasady w Polsce sytuacja prawna jest identyczna, jako że ustawa o ochronie przyrody wprowadza w art. 15 ust. 1 pkt 21 zakaz m.in. pływania i żeglowania, z wyjątkiem akwenów lub szlaków wyznaczonych przez dyrektora parku narodowego. Z drugiej strony nie sposób nie zauważyć, że obszar parku narodowego ma być udostępniany także w celach turystycznych i rekreacyjnych, o ile tylko nie wpłynie negatywnie na przyrodę parku (art. 12 ust. 1). Można nawet przyjąć, że na dyrektorze spoczywa stosowany obowiązek, który powinien zostać zrealizowany poprzez ustalenia planu ochrony.

\subsection{ONDŘEJ VICHA, CHARAKTER PRAWNY WÓD Z PUNKTU WIDZENIA PRZEPISÓW GÓRNICZYCH (PRAVNI POVAHA VOD Z HLEDISKA BAŇSKYCH PŘEDPISÜ)}

Przedstawiając rozwój regulacji prawnych autor wskazuje, że problemom związanym z zalewaniem kopalń było poświęcone już Kutnohorskie prawo górnicze (Ius regale montanorum) nadane przez Wacława II górnikom kutnohorskim około roku 1300. Mimo że głównym celem tego najznaczniejszego źródła średniowiecznego prawa górniczego była regulacja stosunków prawnych w górnictwie, przywiązywało ono znaczną wagę do środków, którymi z jednej strony zapobiegano przenikaniu wód do kopalń, z drugiej umożliwiano odprowadzanie lub odczerpy- 
wanie tych wód z kopalń. Po wzmiance o kolejnych ustawach górniczych na ziemiach czeskich autor przechodzi do prawa obowiązującego, na które składają się trzy kluczowe akty prawne przyjęte w 1988 r.: ustawa górnicza ${ }^{17}$, ustawa o działalności górniczej $^{18}$ i ustawa o pracach geologicznych ${ }^{19}$.

Autor szczególną uwagę poświęca wodom kopalnianym (důlni vody), do których stosuje się ustawę wodną, jeżeli ustawa górnicza nie stanowi inaczej. Tak więc ustawa wodna stosuje się do wód kopalnianych subsydiarnie, ma status lex generalis, podczas gdy ustawa górnicza ma charakter lex specialis. Definicja wód kopalnianych znajduje się w § 40 ust. 1 ustawy górniczej, który za takie uznaje wszystkie podziemne, powierzchniowe i opadowe wody, które przeniknęły do głębinowych lub powierzchniowych przestrzeni kopalnianych, bez względu na to, w jaki sposób przeniknęły. Szczególny reżim wód kopalnianych wynika z $§ 40$ ust. 2 ustawy górniczej. Pierwszeństwo w ich wykorzystaniu ma organizacja, która uzyskała uprawnienia do prowadzenia działalności górniczej. Zdaniem autora należałoby usunąć regulacje odnoszące się do wód kopalnianych z ustawy górniczej i poddać je w całości reżimowi ustawy wodnej traktując je jako ścieki, ale ze zwolnieniem od opłat za wprowadzanie ich do wód powierzchniowych.

W polskim prawie wodnym tzw. wody kopalniane (brakuje ich legalnej definicji) pojawiają się tylko w kontekście unormowań odnoszących się do ścieków. W starszych przepisach funkcjonował natomiast obowiązek przekazywania nadwyżek wód uzyskiwanych z własnych urządzeń wodnych zakładu, o ile nadawały się do picia i potrzeb gospodarczych i rozciągał się także na nadwyżki wód kopalnianych (art. 44 ustawy z dnia 24 października 1974 r. - Prawo wodne). Co do zasady zakładów górniczych nie dotyczył jednak obowiązek przeznaczania

17 Zakon č. 44/1988 Sb., o ochraně a využiti nerostneho bohatstvi (horni zakon).

18 Zakon č. 61/1988 Sb., o hornicke činnosti, vybušinach a o statni baňske spravě.

19 Zakon č. 62/1988 Sb., o geologickych pracich. 
wód podziemnych przede wszystkim na zaspokojenie potrzeb ludności (art. 42 ust. 1).

Obecnie obowiązujące rozporządzenie MŚ z dnia 18 listopada 2014 r. w sprawie warunków, jakie należy spełnić przy wprowadzaniu ścieków do wód lub do ziemi, oraz w sprawie substancji szczególnie szkodliwych dla środowiska wodnego ${ }^{20}$ posługuje się pojęciem „wód pochodzących z odwodnienia zakładu górniczego" (§ 19), będących jedną z kategorii ścieków. Nie są natomiast ściekiem wody pochodzące $\mathrm{z}$ odwodnienia zakładów górniczych, które wtłaczane są do górotworu a rodzaj i ilość zawartych w niej substancji jest tożsamy z rodzajami i ilością takich substancji zwartymi w wodzie pobranej (co wynika z art. 9 ust. 1 pkt 14 lit. e). Prawo wodne nie ingeruje natomiast w sposób gospodarowania takimi wodami w takim zakresie, w jakim czyni to ustawa - Prawo geologiczne i górnicze (art. 8 ust. 1 ustawy - Prawo wodne). Nie wiąże jednak tego wyłączenia z kategorią „wód kopalnianych” czy też „wód pochodzących z odwodnienia zakładów górniczych”, lecz generalnie z wodami podziemnymi (a konkretnie z ich poszukiwaniem i rozpoznawaniem) a także solankami, wodami leczniczymi oraz termalnymi (ale w tym przypadku - co istotne - już bez zastrzeżenia jak wcześniej). Z drugiej strony ustawa - Prawo geologiczne i górnicze ${ }^{21}$ wyraźnie stanowi, że jej przepisów nie stosuje się do korzystania z wód w zakresie uregulowanym w innych przepisach (art. 3 pkt 1 ) a wody, z wyjątkiem wód leczniczych, solanek i termalnych, nie są w ogóle kopalinami (art. 5 ust. 1). Stan prawny w Polsce jest więc co do zasady podobny do czeskiego.

20 Dz.U. z 2014 r., poz. 1800.

21 Ustawa z dnia 9 czerwca 2011 r. Prawo geologiczne i górnicze, tekst jedn. Dz.U. z 2016 r., poz. 1131 ze zm. 


\section{WODA W STOSUNKACH PRYWATNOPRAWNYCH (VODA V SOUKROMOPRAVNICH VZTAZICH)}

\subsection{HANA ADAMOVA, INWESTYCJA WODNA \\ Z PUNKTU WIDZENIA NOWEGO KODEKSU CYWILNEGO \\ (VODNI DILO Z POHLEDU NOVEHO OBČANSKEHO ZAKONIKU)}

Definicja inwestycji wodnych (vodni dila) znajduje się w § 55 ustawy wodnej; są nimi budowle służące piętrzeniu i utrzymywaniu wód, sztucznemu ukierunkowaniu odciekowego reżimu wód powierzchniowych, ochronie i wykorzystaniu wód, postępowaniu z wodami, ochronie przed szkodliwym oddziaływaniem wód, regulacji stosunków wodnych lub innym celom tej ustawy, a zwłaszcza:

a) zapory wodne, groble, zbiorniki wodne, jazy i wody nad nimi,

b) budowle, którymi się reguluje, zmienia lub urządza koryta cieków wodnych,

c) budowle prowadzące wody, obiekty ciśnieniowe, stoki kanalizacyjne, obiekty kanalizacyjne, oczyszczalnie ścieków oraz budowle przeznaczone do czyszczenia ścieków przed wprowadzeniem do kanalizacji,

d) budowle ochrony przed powodziami,

e) budowle wodnomelioracyjne, nawadniające i odwadniające grunty,

f) budowle, które w celach żeglugowych wznosi się w korytach cieków wodnych lub na ich brzegach,

g) budowle do wykorzystania energii wodnej i potencjału energetycznego,

h) budowle wylewisk,

i) budowle służące obserwacji stanu wód powierzchniowych lub podziemnych,

j) studnie,

k) budowle służące grodzeniu bystrzyc i jarów, jeżeli ustawa szczególna (np. ustawa leśna ${ }^{22}$ ) nie stanowi inaczej,

22 Zakon č. 289/1995 Sb., o lesich a o změně a doplněni některych zakonů (lesni zakon). 
1) inne budowle potrzebne do postępowania $z$ wodami, na które uzyskano pozwolenie przewidziane w $\S 8$.

Autorka zastanawia się nad własnością inwestycji (budowli) wodnych w świetle przywróconej w obowiązującym od 1 stycznia 2014 r. kodeksie cywilnym ${ }^{23}$ zasady superficies solo cedit, która prowadzi do wniosku, że są one jako części składowe gruntu zawsze własnością właściciela gruntu, na którym lub pod którym zostały posadowione. Jej zdaniem rozłączenie własności budowli wodnej z własnością gruntu i tym samym przełamanie zasady superficies solo cedit będzie możliwe za pośrednictwem wprowadzonego w kodeksie cywilnym prawa budowy (pravo stavby). Jest ono przedmiotem regulacji $\S 1240$ kodeksu, który stanowi, że grunt może być obciążony prawem rzeczowym innej osoby (stavebnika) do posiadania na lub pod jego powierzchnią budowli (stavby), nie jest przy tym istotne, czy chodzi o budowlę już posadowioną czy dotychczas nieposadowioną. Jak wyjaśniają motywy ustawodawcze do kodeksu cywilnego, pravo stavby nie jest służebnością, lecz szczególnym prawem rzeczowym uznawanym za nieruchomość, sama stavba natomiast samoistną rzeczą nie jest ${ }^{24}$. Ponieważ pravo stavby można nabyć także decyzją władzy publicznej, jeżeli ustawa to przewiduje (§ 1243 kodeksu cywilnego), a jest to w świetle ustawy wodnej możliwe, przeto $\mathrm{w}$ okresie trwania tego prawa (maksymalnie 99 lat, co wynika z § 1244 kodeksu cywilnego), inwestycję wodną należy traktować jako część składową prawa budowy, wobec czego jej właścicielem i tym samym osobą mającą temu odpowiadające prawa i obowiązki będzie właściciel prawa budowy.

Dłuższy czas wydawało się, że na gruncie polskiego Prawa wodnego kwestie własności urządzeń wodnych powinny być wiązane z własnością gruntu pokrytego płynącą wodą powierzchniową, a więc w zgodzie z zasadą superficies solo cedit. Do przełamania takiego nastawienia doprowadził wyrok Na-

23 Zakon č. 89/2012 Sb., občansky zakonik.

24 K. Eliaš a kolektiv, Novy občansky zakonik $s$ aktualizovanou diovodovou zpravou a rejstřikem, Ostrava 2012, s. 536. 
czelnego Sądu Administracyjnego z dnia 16 stycznia 2009 r. $^{25}$ NSA potwierdził, że urządzenia wodne mieszczą się w kręgu ustawowo dopuszczonych wyjątków od kodeksowej zasady superficies solo cedit. Tak więc urządzenia wodne choć są trwale związane z gruntem, nie stanowią jego części składowej.

Z drugiej jednak strony użyte przez ten Sąd argumenty pozostawiają pewien niedosyt, mający swoje źródło w niedopatrzeniach i przemilczeniach. Wniosek sformułowany przez Sąd jest zasadniczo prawidłowy, ale powinien zostać wyprowadzony z logicznych konsekwencji art. 139 ust. 2 ustawy Prawo wodne (dział VI, rozdział 4), przewidującego możliwość przejęcia bez odszkodowania urządzeń wodnych na własność właściciela wody ${ }^{26}$.

\subsection{HANA MÜLLEROVA, SŁUŻEBNOŚCI DOTYCZĄCE WODY} W NOWYM KODEKSIE CYWILNYM

\section{(SLUŽEBNOSTI TYKAJICI SE VODY V NOVEM OBČANSKEM ZAKONIKU)}

Autorka zaczyna od spostrzeżenia, że służebności związane $\mathrm{z}$ postępowaniem $\mathrm{z}$ wodami nie są nowością $\mathrm{w}$ czeskim porządku prawnym. Były znane powszechnemu kodeksowi cywilnemu austriackiemu z 1811 r., a czechosłowacki kodeks cywilny z 1964 r. wprawdzie ich wprost nie regulował, ale ich nie wykluczał jako przewidzianych w nim ciężarów rzeczowych. Nowy czeski kodeks cywilny uregulował wprost trzy służebności dotyczące wody, które zalicza się do służebności historycznych, a to:

1) służebność okapu (§ 1270) - prawo odprowadzania wody deszczowej ze swego dachu na cudzą nieruchomość,

25 Sygn. akt II OSK 1874/07.

26 Zob. J. Rotko, Własność $i$ zarząd urządzeniami wodnymi $w$ orzecznictwie sądów administracyjnych, „Studia Prawnicze” 2014, Nr 3, s. 85 i n. oraz tam cyt. literatura. 
2) prawo do odprowadzania wody deszczowej (§ 1271) prawo pobierania wody deszczowej z sąsiedniego dachu,

3) prawo do wody (§ 1272), według którego, kto ma prawo do wody na cudzym gruncie, ma też do niej dostęp, a kto ma prawo sprowadzać wodę z cudzego gruntu na swój albo odprowadzać wodę ze swego gruntu na cudzy, może na swój koszt sporządzić i utrzymywać urządzenia potrzebne do tego; ich zakres określa się według potrzeb gruntu władnącego.

We wnioskach autorka wskazuje, że instytucję służebności dotyczących wody uregulowaną w nowym kodeksie cywilnym jako instytucję prawa prywatnego należy widzieć w ścisłym związku z wymaganiami wypływającymi z regulacji prawnej ochrony wód. Wykonywanie służebności nie może być dowolne, ale musi kierować się również odpowiednimi przepisami ustawy wodnej, z których wynika także ich tytuł publicznoprawny.

W polskim prawie uregulowane zostały tylko te przypadki (traktowane jako wyjątek od reguły), w jakich podlegają obrotowi cywilnoprawnemu płynące wody publiczne oraz grunty pod takimi wodami. Nie ma natomiast rozwiązań podobnych do czeskich, które powiązane zostały z wodami deszczowymi oraz wodą na cudzym gruncie.

\subsection{ZBYNĚK LUBOVSKY, NAPRAWIENIE SZKODY W RYBACTWIE (NARADA ŠKODY V RYBAĽSTVI)}

W Republice Czeskiej chów ryb i innych zwierząt wodnych jest wykonywany albo na stawach (rybnikařstvi), albo w obwodach rybackich. Ze względu na to, że dzieje się to w wolnej przyrodzie, życie ryb w środowisku wodnym jest zagrożone nie tylko przez kłusowników, ale przede wszystkim pogorszeniem jakości wody, presją drapieżników żywiących się rybami oraz zjawiskami siły wyższej, zwłaszcza powodziami. 
Na tle przepisów kodeksu cywilnego autor przedstawia trzy pojęcia:

1) szkody w ogólności składającej się ze szkody rzeczywistej i nieosiągniętego zysku,

2) szkody ekologicznej jako szkody powstałej w komponentach środowiska, ale mającej zawsze charakter majątkowy,

3) ujmy ekologicznej jako straty lub osłabienia naturalnych funkcji ekosystemu, która nie musi mieć charakteru majątkowego.

Czeska ustawa rybacka ${ }^{27}$ ani inny akt prawny nie rozwiązuje wprost kwestii własności dziko żyjących ryb. W odróżnieniu od ryb w stawach, nie jest możliwa konstrukcja własności ryb w wodach płynących, w nich ryby niewyłowione uznaje się za niczyje, a ich własność nabywa uprawniony do rybactwa w obwodzie rybackim przez ich wyłowienie. Ponieważ niewyłowione ryby nie są przedmiotem własności, przeto zgodnie z ustalonym orzecznictwem sądów czeskich w razie wyrządzenia szkody naprawia się tylko nieosiągnięty zysk czy też nakłady wyłożone na chów ryb.

Podstawowa regulacja dotycząca odszkodowań została zamieszczona w $\S 12$ ust. 11 ustawy rybackiej, który głosi, że za szkodę wyrządzoną w obsadzie rybackiej w obwodzie rybackim lub stawie albo w szczególnych urządzeniach hodowlanych odpowiada osoba, która ją wyrządziła. Do dochodzenia odszkodowania jest uprawniony użytkownik obwodu rybackiego (uživatel rybařskeho reviru) albo rybak stawowy (rybnikă̌). W literaturze cywilistycznej przyjmuje się, że z ogólnego sformułowania tego przepisu należy wnosić, że chodzi o obowiązek dania odszkodowania bez względu na zawinienie ${ }^{28}$.

Szczególnym przypadkiem odpowiedzialności odszkodowawczej jest rekompensata za szkody spowodowane przez

27 Zakon č. 99/2004 Sb., o rybnikařstvi, vykonu rybařskeho prava, rybařske straži, ochraně mořskych rybolovnych zdrojů a o změně některych zakonů (zakon o rybařstvi).

28 J. Psutka, Odpovědnost za ekologicke škody v občanskem pravu, Praha 2011, s. 350. 
zwierzęta. Punktem wyjścia jest tu czeska ustawa łowiecka ${ }^{29}$, która w $\S 54$ ust. 1 i 2 reguluje odpowiedzialność za szkody wyrządzone przez zwierzęta łowne, po czym w ust. 3 stanowi, że szkody spowodowane przez zwierzynę, której stany liczbowe nie mogą być obniżane łowem, są naprawiane przez państwo, precyzując w tzw. poznamce pod čarou (uwadze pod kreską) ${ }^{30}$, że chodzi o szczególną ustawę o odpowiedzialności za szkody wyrządzone przez gatunki chronione ${ }^{31}$. Do takich gatunków ustawa zalicza: bobra, wydrę, kormorana, łosia, niedźwiedzia, rysia i wilka. W odniesieniu do szkód w rybactwie wchodzi w rachubę przede wszystkim kormoran oraz wydra. Problem dotyczy innych zwierząt. Autor szkicu przychyla się do stanowiska komentatorów ustawy łowieckiej, że poznamka pod čarou nie ma charakteru normatywnego, a zatem nie jest wykluczone dochodzenie od państwa odszkodowania za szkody spowodowane $\mathrm{w}$ gospodarstwach rybackich za inne zwierzęta $^{32}$.

Dalej autor analizuje odpowiedzialność za szkody spowodowane eksploatacją urządzeń w następstwie wprowadzenia substancji zanieczyszczających do wód lub manipulacjami poziomem wody, której podstawą może być § 2924 kodeksu cywilnego (škoda z provozni činnosti - szkoda wyrządzona ruchem/eksploatacją/urządzenia), oraz odpowiedzialność kłusowników w procesie adhezyjnym. Jeśli chodzi o szkody spowodowane przez powódź autor powiada, że poszkodowani mogą się starać o uzyskanie środków finansowych na złago-

29 Zakon č. 449/2001 Sb., o myslivosti.

30 Ustawodawca czeski, jeżeli w tekście przepisu danej ustawy odsyła do innej, posługuje się odsyłaczem i dalej „pod kreską” wskazuje, do jakiej ustawy odsyła. To jest ta poznamka pod čarou. W literaturze toczą się spory, czy ta poznamka ma charakter normatywny, czyli ogranicza interpretację do wskazanej ustawy, czy też nie ma takiego charakteru, co umożliwia sięganie i do innych ustaw, w owej poznamce niewymienionych.

31 Zakon č. 115/2000 Sb., o poskytovani nahrad škod způsobenych vybranymi zvlaště chraněnymi živočichy.

32 V. Čechura a kolektiv, Komentař k zakonu o myslivosti, Praha 2002, s. 197. Podobnie B. Petr a kolektiv, Zakon o myslivosti. Komentar̆, Praha 2015, s. $220-221$. 
dzenie następstw powodzi, ale nie przysługuje im na to roszczenie prawne.

Problematyka szkód $\mathrm{w}$ rybactwie ma wiele aspektów i pomimo różnic $\mathrm{w}$ regulacjach większość prezentowanych przez autorów czeskich poglądów jest zbieżna z tezami polskich komentatorów. Inaczej jednak niż w Czechach w polskiej ustawie - Prawo wodne uregulowano status prawny ryb oraz innych organizmów żyjących w wodzie. Uznane bowiem zostały za jej pożytki, do pobierania których uprawniony jest właściciel wody (art. 13 ust. 1). Jeśli chodzi o szkody wywołane powodzią, to dochodzenie związanych z nią roszczeń jest możliwe, o ile można wykazać ich związek z nieprzestrzeganiem przepisów ustawy przez właściciela wody lub właściciela urządzenia wodnego (art. 16 ust. 3).

\section{OCHRONA JAKOŚCI WÓD (OCHRANA KVALITY VOD)}

\subsection{JAROSLAV CHYBA, CZY DOBRY STAN \\ WÓD POWIERZCHNIOWYCH JEST REALNIE OSIĄGALNY? \\ (JE DOBRY STAV POVRCHOVYCH VOD REALNĚ DOSAŽITELNY?)}

Po przeprowadzeniu rzetelnej analizy stanu jakości wód autor wywodzi, że za dotrzymanie wymagań jakości wód określonych dyrektywami unijnymi odpowiada Republika Czeska. W płaszczyźnie wewnątrzpaństwowej odpowiedzialność nie jest ani nie może być sprawiedliwie adresowana do nikogo. Realnie można wymagać tylko monitorowania wód i realizacji opartego na nim projektu stopniowej, krok po kroku, naprawy. W każdym razie osiągnięcie odpowiedniego stanu chemicznego wód w zakreślonym ustawa wodną terminie 22 grudnia 2015 r. nie jest osiągalne.

Pytanie postawione przez autora tego fragmentu książki jest dość przewrotne. Zauważyć należy, że płynący z ramowej 1/2016 dyrektywy wodnej (przejęty do ustawy) obowiązek osiągnięcia 
dobrego stanu wód do 22 grudnia 2015 r. nie jest bezwzględny. Także prawodawca europejski zdawał sobie sprawę z trudności, jakie towarzyszyć będą realizowaniu programu dyrektywy i dlatego dopuścił szereg zdroworozsądkowych wyjątków. Również w Polsce nie udało się w tym terminie osiągnąć dobrego stanu wszystkich wód. Nie znaczy to jednak, że program legislacyjny się załamał a postulat jest nierealny i przebrzmiały. Co do odpowiedzialności w płaszczyźnie wewnątrzpaństwowej, to przyjąć można, że za realizację polityki ochrony wód odpowiedzialność polityczną ponosi Minister Środowiska.

\subsection{JANA TKAČIKOVA, DYREKTYWA AZOTANOWA - ZAGADNIENIA IMPLEMENTACJI (NITRATOVA SMĚRNICE - OTAZKY IMPLEMENTACE)}

Autorka zajęła się implementacją w Republice Czeskiej dyrektywy Rady 91/676/EWG o ochronie wód przez zanieczyszczeniem azotanami ze źródeł rolniczych ${ }^{33}$. Podstawą normatywną jest § 33 ustawy wodnej dotyczący obszarów wrażliwych (zranitelne oblasti) zaliczający do nich obszary, na których występują:

a) wody powierzchniowe lub podziemne, zwłaszcza wykorzystywane lub przeznaczone jako zasoby wody pitnej, w których koncentracje azotanów przekraczają $50 \mathrm{mg} / \mathrm{l}$ albo mogą tę wysokość osiągnąć, albo

b) wody powierzchniowe, w których w następstwie wysokiej koncentracji azotanów ze źródeł rolniczych dochodzi lub może dojść do niepożądanego pogorszenia jakości wody.

Do tych przepisów ukazały się wykonawcze rozporządzenia rządowe najpierw w 2003 r., następnie w 2012 r. Za wyznaczenie obszarów wrażliwych jest odpowiedzialne Ministerstwo Środowiska jako centralny organ administracji państwowej

33 Dyrektywa Rady z dnia 12 grudnia 1991 r. dotycząca ochrony wód przed zanieczyszczeniami powodowanymi przez azotany pochodzenia rolniczego, Dz.Urz. UE L 375 z 31.12.1991, s. 1-8. 
w sprawach ochrony jakości wód powierzchniowych i podziemnych. Obecnie obszary wrażliwe stanowią 41,6 \% powierzchni Republiki Czeskiej i obejmują 1850000 ha ziemi rolniczej.

Rozporządzenie wykonawcze z 2012 r. zawiera trzeci już z kolei program działania, za którego przeprowadzenie i modyfikacje jest odpowiedzialne Ministerstwo Rolnictwa. Powierzyło ono to zadanie do wykonania Instytutowi Badawczemu Produkcji Roślinnej jako instytucji naukowo-badawczej. Funkcje nadzoru ogólnego sprawuje Czeska Inspekcja Środowiska.

Komisja Europejska nie ma większych zastrzeżeń pod adresem implementacji tej dyrektywy w Republice Czeskiej.

Kończąc, autorka zwróciła uwagę, że należyte wdrożenie dyrektywy azotanowej jest ważną przesłanką osiągnięcia celów ramowej dyrektywy wodnej. Tak jak i inne dyrektywy z dziedziny środowiska, tak też faktyczne skutki dyrektywy azotanowej są osłabiane implementačnim deficitem, którego przyczyn należy upatrywać tak po stronie państw członkowskich Unii Europejskiej, jak i po stronie samych dyrektyw (niejasne definicje, nieokreślone kryteria wyznaczania ściślej chronionych obszarów, niejednoznaczne określenie obowiązków). Dotyczy to także dyrektywy azotanowej, która jest stałym przedmiotem sporów.

Inaczej niż w Czechach, w Polsce implementacja dyrektywy azotanowej wywoływała i wywołuje gorące spory, zwłaszcza w kontekście krytyki płynącej z Komisji Europejskiej. Także kraje sąsiedzkie, zwłaszcza posiadające dostęp do Morza Bałtyckiego, przypominają, że to polskie rolnictwo jest odpowiedzialne w dużej mierze za potężny ładunek azotu, jaki do niego trafia. Podkreślić jednak należy, że Polska stworzyła i uruchomiła wszystkie instrumenty realizacyjne, konieczne dla wdrożenia dyrektywy azotanowej.

\subsection{HANA MUSILOVA, ZANIECZYSZCZENIE WODY OŁOWIEM - CZY TO WINA MYŚLIWYCH? (ZNEČISTĚNI VODY OLOVEM - JE TO VINA MYSLIVCU゚?)}

Autorka wychodzi od przepisów ustawy wodnej doty1/2016 czących ochrony jakości wód. Jest ona zagrożona nie tylko 
wpływami przyrodniczymi, ale zwłaszcza antropogenicznymi. Głównymi źródłami zagrożenia jakości wód powierzchniowych i podziemnych są awarie, ścieki i substancje zagrażające jakości wód (zavadne latky). Wśród nich znajduje się ołów umieszczony na kilku urzędowych listach takich substancji. Jego właściwością niepożądaną dla środowiska jest zdolność bioakumulacji, tj. gromadzenia się nie tylko w sedymentach i odciekach, ale także w biomasie organizmów i roślin. Ołów jest oceniany jako wysoce toksyczny dla środowiska wodnego, zwłaszcza dla zooplanktonu i zwierząt żyjących na dnie.

Ołów przenika do przyrody, a więc i do wody z różnych źródeł: ścieki przemysłowe, spływ ze źle zabezpieczonych składowisk odpadów, korodujące ołowiane rury itp. Ale obok tych „klasycznych” źródeł pojawiają się myśliwi, którzy strzelają do ptactwa nabojami śrutowymi. Śrut wpada nie tylko na glebę, ale i do wody czy na tereny podmokłe i jest szkodliwy dla ptaków, które mogą połykać śruciny biorąc je za pokarm bądź kamyki. W żołądkach ptaków śruciny mogą się rozpuszczać powodując istotne szkody.

Już w tekście pierwotnym z 2001 r. czeskiej ustawy łowieckiej znajdował się przepis § 45 ust. 1 lit. w) zakazujący używania nabojów ze śrutem ołowianym przy polowaniu na ptactwo wodne, ale jego wejście w życie zostało przesunięte o 10 lat. Przed rozpoczęciem sezonu polowań w 2011 r. zakaz stał się przedmiotem zmasowanej krytyki ze strony myśliwych, którzy nie dostrzegli, że wprowadzenie takiego zakazu było międzynarodowym obowiązkiem Republiki Czeskiej wynikającym z Konwencji Berneńskiej o ochronie europejskiej fauny i flory ${ }^{34}$, z zwłaszcza z przyjętego w 1991 r. planu działań realizujących Porozumienie o ochronie afro-euroazjatyckiego wędrownego ptactwa wodnego, które z kolei jest aktem realizacyjnym do Konwencji Bońskiej z 1979 r. o ochronie gatunków wędrownych ${ }^{35}$. Porozumienie przewidywało, że strony będą

34 Konwencja o ochronie gatunków dzikiej flory i fauny europejskiej oraz ich siedlisk z dnia 19 września 1979 r., Dz.U. z 1996 r. Nr 58, poz. 263.

35 Konwencja z dnia 23 czerwca 1979 r. o ochronie wędrownych gatunków dzikich zwierząt, Dz.U. z 2003 r. Nr 2, poz. 17. 
dążyć do wstrzymania stosowania śrutu ołowianego do końca 2000 r. Republika Czeska przystąpiła do Porozumienia z 2006 r. i wynegocjowała wyjątek do 1 stycznia 2011 r. Krytyka ustawodawcy przez myśliwych miała podstawy, bo obowiązkiem międzynarodowym był zakaz stosowania śrutu ołowianego tylko na mokradłach, podczas gdy czeski ustawodawca wprowadził generalny zakaz w odniesieniu do polowania na ptactwo wodne. Alternatywą okazał się śrut wytwarzany z bizmutu, wolframu, cynku, cyny lub stali. Ze względu na koszty w rachubę wchodził praktycznie tylko śrut stalowy, ale okazało się, że śrut stalowy w porównaniu z ołowianym ma gorsze właściwości i może spowodować większe cierpienie trafionych ptaków. Mniejsza energia kinetyczna powoduje, że ptak bardziej krwawi i nie pada od razu, tak jak to jest przy trafieniu śrutem ołowianym, lecz odlatuje nawet na większą odległość. Poza tym rozkładający się śrut stalowy może spowodować zanieczyszczenie wody żelazem. Wreszcie stosowanie śrutu stalowego zwiększa zagrożenie dla samych myśliwych. Niektórzy myśliwi odmówili stosowania się do zakazu, ryzykując odpowiedzialność za wykroczenie. W sukurs przyszedł im ustawodawca nowelizując w 2013 r. § 45 ust. 1 lit. w) ustawy łowieckiej i od 1 lipca 2014 r. obowiązuje zakaz używania nabojów śrutowych przy polowaniu na wodne ptactwo tylko na mokradłach, tak jak tego wymagają międzynarodowe zobowiązania Republiki Czeskiej, a nie w ogóle, jak było przed nowelizacją.

Autorka kończy uwagą, że zakaz używania nabojów ze śrutem ołowianym jest przykładem ograniczenia zachowania człowieka in favorem wodnego ptactwa, ochrony mokradeł, ochrony wód i zwierząt wodnych. Ta ochrona jest z pewnością ważna, ale nie można na nią spoglądać w sposób wyizolowany i zapominać, że istnieją i inne interesy z dziedziny środowiska, z którymi należy zestawić jakość wody. W przypadku łowiectwa i polowania na ptactwo wodne chodzi zwłaszcza o ochronę zwierząt przed cierpieniami i o bezpieczeństwo na polowaniach.

Omawiany problem nie został jeszcze w Polsce dostrzeżony przez prawodawcę, mimo że organizacje ekologiczne zwracają uwagę na niebezpieczeństwa środowiskowe związane 1/2016 z ołowianą amunicją. 


\subsection{JANA DUDOVA, HIGIENICZNE ASPEKTY JAKOŚCI WÓD (HYGIENICKE ASPEKTY KVALITY WOD)}

Autorka zaczyna od spostrzeżenia, że higieniczna ochrona wody ma zupełnie podstawowe znaczenie nie tylko z punktu widzenia gwarancji jakości wody pitnej, ale także w odniesieniu do wód służących do innych celów, przy których bezpośrednio lub pośrednio może być zagrożone ludzkie zdrowie (np. woda do mycia lub kąpieli, woda służąca do nawadniania, woda w produkcji środków spożywczych itp.).

Regulacja prawna jakości wód jest w warunkach Republiki Czeskiej rozproszona między kilka podstawowych ustaw. Obok samej ustawy wodnej jest to zwłaszcza ustawa o ochronie zdrowia publicznego ${ }^{36}$ oraz ustawa o wodociągach i kanalizacji ${ }^{37}$. Bliższe aspekty są uregulowane w przepisach wykonawczych. Tak ustawiona regulacja jest nieprzejrzysta, co odbija się także na organizacyjnym zabezpieczeniu. Tylko z dużymi wątpliwościami można zakładać, że organy ochrony zdrowia mogą prewencyjnie (w nawiązaniu do najlepszych dostępnych technik) wpływać na jakość wód z punktu widzenia czynników ryzykownych dla zdrowia człowieka. Trzeba wychodzić z ustawy o zintegrowanej prewencji zanieczyszczeń ${ }^{38}$. Reżim prawny tej ustawy jest z punktu widzenia aspektów higienicznych czy też oceny ryzyk zdrowotnych przy określaniu i ocenianiu najlepszych dostępnych technik (BAT) mocno problematyczny, brakuje bowiem uczestnictwa fachowców, którzy byliby uprawnieni do przedstawiania stanowiska wobec najlepszych dostępnych technik z punktu widzenia ryzyk zdrowotnych dla człowieka.

Przepisy dotyczące różnych aspektów jakości wód także w Polsce znajdziemy w wielu odrębnych ustawach. Akcent położony na aspekty higieniczne zawęża nieco zakres regulacji, choć

36 Zakon č. 258/2000 Sb., o ochraně veřejneho zdravi.

37 Zakon č. 274/2001 Sb., o vodovodech a kanalizacich pro veřejnou potřebu a o změně některych zakonů (zakon o vodovodech a kanalizacich).

38 Zakon č. 76/2002 Sb., o integrovane prevenci a omezovani znečištěni, o integrovanem registru znečišt'ovani a o změně některych zakonů (zakon o integrovane prevenci). 
i tak wskazywać możemy co najmniej na: a) przepisy Prawa wodnego - w kontekście jakości wody w kąpieliskach), b) przepisy ustawy z 25 sierpnia 2006 r. o bezpieczeństwie żywności i żywienia ${ }^{39}$ - w kontekście jakości wód mineralnych, naturalnych wód źródlanych oraz wód stołowych; wymagania ich dotyczące określa rozporządzenie Ministra Zdrowia z dnia 31 marca 2011 r. w sprawie naturalnych wód mineralnych, wód źródlanych i wód stołowych ${ }^{40}$, c) przepisy prawa farmaceutycznego, tj. ustawy z dnia 6 września 2001 r. - Prawo farmaceutyczne ${ }^{41}$, które znajdą zastosowanie w odniesieniu do wód leczniczych. Najważniejsze wydają się jednak unormowania rozporządzenia MZ z dnia 29 marca 2007 r. w sprawie jakości wody przeznaczonej do spożycia przez ludzi, wydanego na podstawie ustawy z dnia 7 czerwca 2001 r. o zbiorowym zaopatrzeniu w wodę i zbiorowym odprowadzaniu ścieków ${ }^{42}$. Nadzór nad jakością wody do spożycia sprawują organy Państwowej Inspekcji Sanitarnej oraz organ wykonawczy gminy. W tym zakresie potwierdzić trzeba niepokój autorów czeskich, związany z pozostawaniem poza zainteresowaniem prawodawcy słabo rozpoznanych ryzyk, związanych choćby $\mathrm{z}$ obecnością $\mathrm{w}$ wodzie pobieranej ze środowiska metabolitów zawierających resztki antybiotyków, leków przeciwrakowych, hormonów czy środków antydepresyjnych.

\subsection{TEREZA SNOPKOVA, OCHRONA WÓD W POZWOLENIU ZINTEGROWANYM (OCHRANA VOD V INTEGROVANEM POVOLENI)}

Autorka wskazuje, że ustawa z 2002 r. o zintegrowanej prewencji, powoływana jako „ustawa IPPC” zajmuje się wodą już od swego powstania, tj. od wejścia w życie z dniem 1 stycznia 2003 r. Istotne zmiany przyniosła ustawa z 2013 r. noweli-

39 Dz.U. z 2010 r. Nr 136, poz. 914 ze zm.

40 Tekst jedn. Dz.U. Nr 85, poz. 466.

41 Dz.U. Nr 126, poz. 1381 ze zm.

42 Tekst jedn. Dz.U. z 2015 r., poz. 139 z późn. zm. 
zująca ustawę IPPC. Ta zmiana jest konsekwencją transpozycji dyrektywy unijnej 2010/75/UE o emisjach przemysłowych ${ }^{43}$. Nowością jest pojawienie się w ustawie IPPC „podstawowego sprawozdania" (zakladni zprava) przedstawiającego informacje o stanie zanieczyszczenia gleby i wód podziemnych przez określone substancje niebezpieczne. To podstawowe sprawozdanie można uznawać za dobry instrument oceny zmian w zakresie eksploatacji instalacji, która przez wykorzystanie niebezpiecznych substancji negatywnie wpływa na wody podziemne i/lub glebę, a w konsekwencji nałożenia obowiązku przywrócenia do stanu poprzedniego. Jednakże autorka za podstawowy instrument uznaje stosowanie najlepszych dostępnych technologii i właśnie w ich uwzględnieniu w wiążących warunkach zintegrowanego pozwolenia dopatruje się środka wykonania warunków ochrony wód podziemnych i gleby.

Instrumentarium pozostające do dyspozycji polskich organów administracji ochrony środowiska nie różni się od tego w Czechach. Odmienności dostrzegamy w wyborze wariantu legislacyjnego, jako że w Polsce jest to niezmiennie materia ustawy - Prawo ochrony środowiska ${ }^{44}$, podczas gdy w Czechach funkcjonuje odrębna ustawa.

\subsection{PETRA HUMLIČKOVA, ODPOWIEDZIALNOŚĆ ZA STRATY W WODACH (ODPOVĚDNOST ZA ZTRATY NA VODECH)}

Autorka wychodzi od powszechnie akceptowanej w czeskiej literaturze prawniczej koncepcji odpowiedzialności prawnej jako powinności wtórnej wynikającej z naruszenia powinności pierwotnej. Ta powinność wtórna to przede wszystkim przedsięwzięcia prewencyjne i naprawcze.

43 Dyrektywa Parlamentu Europejskiego i Rady 2010/75/UE z dnia 24 listopada 2010 r. w sprawie emisji przemysłowych (zintegrowane zapobieganie zanieczyszczeniom i ich kontrola), Dz.Urz. UE L 334 z 17.12.2010, s. 17-119.

44 Ustawa z dnia 27 kwietnia 2001 r. Prawo ochrony środowiska, tekst jedn. Dz.U. z 2016 r., poz. 672 ze zm. 
Ustawa wodna w § 42 przewiduje odpowiedzialność za straty w wodach polegającą na tym, że urząd wodnoprawny lub Czeska Inspekcja Środowiska zobowiązuje do podjęcia przedsięwzięć naprawczych mających na celu usunięcie następstw taksatywnie wymienionych działań i stanów, które ustawa określa mianem wadliwego stanu (zavadny stav). Chodzi o:

- niedozwolone odprowadzanie ścieków,

- niedozwolone postępowania z substancjami mogącymi zagrozić jakości wód powierzchniowych lub podziemnych (zavadne latky),

- awarie.

Jak wskazują komentatorzy, z ustawy wodnej wynika, że do zagrożenia jakości wód powierzchniowych lub podziemnych może dojść przy odprowadzaniu ścieków lub przy obchodzeniu się z określonymi substancjami. Każda z tych problematyk została uregulowana osobno i odmiennie. Jeśli chodzi o ścieki lub wody kopalniane, to nie może chodzić o zavadne latky, i odwrotnie. Zavadnymi latkami mogą być np. odpady biologiczne lub osady z oczyszczalni ścieków ${ }^{45}$.

Zdaniem autorki, jeśli chodzi o dwie pierwsze sytuacje, to mamy do czynienia z odpowiedzialnością opartą na naruszeniu obowiązku prawnego wynikającego bezpośrednio z ustawy lub z decyzji. Trzecim przypadkiem jest awaria zdefiniowana w § 40 ustawy wodnej jako nadzwyczajne pogorszenie lub zagrożenie jakości (ale nie ilości) wód. W przepisie są wskazane tytułem przykładów awarie wynikające m.in. z zanieczyszczenia substancjami ropopochodnymi, zanieczyszczenia w strefach ochronnych, uszkodzenia urządzeń służących postępowaniu ze szczególnie niebezpiecznymi substancjami. Wprawdzie pojęcie awarii nie wskazuje na naruszenie obowiązku prawnego, ale jeśli wziąć pod uwagę bardzo szczegółowe regulacje dotyczące zapobiegania awariom, to nie można rozsądnie zakładać powstanie nadzwyczajnego poważnego pogorszenia lub zagrożenia jakości wód działaniami zgodnymi z prawem. Konkluzja

45 Z. Horaček, M. Kral, Z. Strnad, V. Vytejčkova, Vodni zakon s podrobnym komentařem po velke novele stavebniho zakona k 1.1.2013, Praha 2012, s. 122. 
autorki jest więc taka, że odpowiedzialność za straty w wodach jest praktycznie oparta na naruszeniu obowiązku prawnego.

Istotne jest, że straty w wodach mogą podlegać także specjalnej ustawie o szkodzie ekologicznej ${ }^{46}$ wdrażającej do czeskiego systemu prawnego dyrektywę 2004/35/WE ${ }^{47}$. Powstaje wobec tego pytanie, jaka jest relacja między tymi przepisami. Sama ustawa wodna w $\S 126$ ust. 7 stanowi, że obowiązku podjęcia przedsięwzięć naprawczych, o których mowa w § 42 tej ustawy, nie nakłada się, jeżeli została wydana decyzja na podstawie ustawy o szkodzie ekologicznej. Zasada specjalności ustawy o szkodzie ekologicznej w stosunku do ustawy wodnej i innych ustaw dotyczących komponentów środowiska została także ujęta w $\S 21$ ust. 3 ustawy o szkodzie ekologicznej ${ }^{48}$. Generalna zasada jest zatem taka, że reżimu nakładania obowiązku podejmowania przedsięwzięć naprawczych nie stosuje się, jeżeli strata podpada pod reżim ustawy o szkodzie ekologicznej. Tymczasem w praktyce jest inaczej. Autorka wskazuje na rok 2012, w którym na terytorium Republiki Czeskiej doszło do 58 awarii na wodach, a Czeska Inspekcja Środowiska nałożyła obowiązek podjęcia środków naprawczych w 76 przypadkach, ale zawsze na podstawie $\S 42$ ustawy wodnej. Ten rok nie był zresztą wyjątkowy, dane za pozostałe lata są podobne. Okazuje się, że reżim ustawy o szkodzie ekologicznej, która weszła w życie w 2008 r. nie został w Czechach ani razu zastosowany.

Po szczegółowym przedstawieniu reżimu przedsięwzięć naprawczych przewidzianego w § 42 ustawy wodnej zróżnicowanego w zależności od tego, czy sprawca zavadneho stavu jest znany (wtedy obowiązek nakłada się na niego, a jeżeli zwłoka grozi niebezpieczeństwem przedsięwzięcia realizuje urząd wod-

46 Zakon č. 167/2008 Sb., o předchazeni ekologicke ujmě a io jeji napravě a o změně některych zakonů.

47 Dyrektywa 2004/35/WE Parlamentu Europejskiego i Rady z dnia 21 kwietnia 2004 r. w sprawie odpowiedzialności za środowisko w odniesieniu do zapobiegania i zaradzania szkodom wyrządzonym środowisku naturalnemu, Dz.Urz. UE L 143 z 30.4.2004, s. 56-75.

48 Szerzej zob. V. Stejskal, O.Vicha, Zakon o předchazeni ekologicke ujmě a o jeji napravě s komentařem, souvisicimi predpisy a s uvodem do problematiky ekologicko-pravni odpovědnosti, Praha 2009, s. 150 i n. 
noprawny lub Czeska Inspekcja Środowiska na koszt sprawcy), czy też nie jest znany (wtedy przedsięwzięcia podejmuje urząd wodnoprawny, który może zlecić ich przeprowadzenie przedsiębiorcy przygotowanemu do tego faktycznie i technicznie, mimo że nie ma on nic wspólnego z zavadnym stavem, zapewniając finansowanie ze specjalnego funduszu). Autorka dochodzi do wniosku, że nie jest całkiem jasne, kiedy w przypadkach strat w wodach postępuje się według reżimu ustawy wodnej, a kiedy według reżimu ustawy o szkodzie ekologicznej. Praktyka stosuje wyłącznie przepisy ustawy wodnej, co nasuwa pewne wątpliwości co do zgodności z prawem nakładanych obowiązków. Dlatego, jej zdaniem, należałoby doprecyzować przepisy o konkurujących regulacjach.

Formy odpowiedzialności za naruszenie przepisów służących ochronie wód są w Polsce mocno rozbudowane i nie ograniczają się do unormowań ustawy - Prawo wodne. Co więcej, te inne przepisy odgrywają być może nawet poważniejszą rolę. Regulacje Prawa wodnego to $\mathrm{z}$ jednej strony nieliczne przepisy karne w dziale IX oraz, z drugiej, formy odpowiedzialności wyrażające się w cofaniu lub ograniczaniu udzielonych pozwoleń wodnoprawnych. Kluczowe znaczenie mają natomiast środki finansowo-prawne uregulowane przepisami ustawy - Prawo ochrony środowiska, choć nie wszystkim z nich przypisać można charakter sankcyjny. Podobnie jak w Czechach, praktycznie doniosłą rolę $\mathrm{w}$ zapobieganiu szkodom $\mathrm{w}$ wodach i naprawianiu szkód odgrywa odrębna ustawa z dnia 13 kwietnia 2007 r. o zapobieganiu szkodom $\mathrm{w}$ środowisku i ich naprawie ${ }^{49}$. Ustawa - Prawo wodne wyraźnie do niej odsyła w art. 185 ust. 2, wobec czego nie ma - jak w Czechach - problemu, według jakiego reżimu wymierzać odpowiedzialność za szkody. Kolejna różnica to nieobecność w polskim Prawie wodnym rozbudowanych przepisów poświęconych zagrożeniom związanym z produktami i substancjami innymi niż te zaliczone do ścieków. Nie zmienia tej oceny fakt, że ustawa zawiera generalny zakaz wprowadzania do wód odpadów, spławiania zanieczyszczonego śniegu, używania do konserwacji technicznych konstrukcji pod- 
wodnych farb na bazie związków organiczno-cynowych (art. 40 pkt 1, 2 i 6).

Wnioski płynące $\mathrm{z}$ powyższego przeglądu problemów pojawiających się w czeskiej i polskiej nauce prawa wodnego wskazują na szereg podobieństw. Nie ma w tym niczego nadzwyczajnego, jako że rozwiązania przyjmowane w ustawodawstwie dotyczącym gospodarowania wodami muszą się zmierzyć z porównywalnymi problemami cywilizacyjnymi. Innym czynnikiem unifikującym jest konieczność transpozycji i wdrożenia dyrektyw europejskich. Nie wszystkie unormowania są rzecz jasna identyczne. Wynika to przede wszystkim z odmienności ustroju administracyjnego, jak i tradycji prawnych i prawniczych.

Problemy przyjęte do omówienia przez autorów czeskich w pracy Voda v pravnich vztazich są wielorakie, choć nie jest to ich zamknięta, niejako wzorcowa lista. Tak w Czechach, jak i w Polsce, wiele kontrowersji wywołuje także na przykład problematyka utrzymania i regulacji wód w zgodzie z wymaganiami ochrony środowiska, niepodjęta w prezentowanej pracy. Szereg problemów stwarza także posługiwanie się instrumentami planistycznymi, stworzonymi w ramowej dyrektywie wodnej. Mimo to rozległe i wnikliwe analizy czeskich autorów potwierdzają istnienie znaczącego dorobku naukowego związanego $\mathrm{z}$ prawem wodnym oraz inspirują do prowadzenia podobnych badań także w Polsce.

\section{BIBLIOGRAFIA}

Čechura V. a kolektiv, Komentař k zakonu o myslivosti, Praha 2002.

Eliaš K. a kolektiv, Novy občansky zakonik s aktualizovanou di̊vodovou zpravou a rejstrikem, Ostrava 2012.

Horaček Z., Kral M., Strnad Z., Vytejčkova V., Vodni zakon z podrobnym komentařem po velke novele stavebniho zakona $k$ 1.1.2013, Praha 2013.

Petr B. a kolektiv, Zakon o myslivosti. Komentař, Praha 2015.

Prawo wodne. Komentarz, B. Rakoczy (red.), Warszawa 2013.

Průcha P., Klikova A., Veřejne stavebni pravo, Brno 2014. 
Psutka J., Odpovědnost za ekologicke škody v občanskem pravu, Praha 2011.

Rotko J., Wtasność $i$ zarząd urządzeniami wodnymi $w$ orzecznictwie sadów administracyjnych, „Studia Prawnicze” 2014, Nr 3.

Stejskal V., Vicha O., Zakon o predchazeni ekologicke ujmě a o jeji napravěs komentařem, souvisicimi predpisy a s uvodem do problematiky ekologicko-pravni odpovědnosti, Praha 2009.

Kontakt e-mail:

rotkojerzy@poczta.onet.pl 